\title{
An Integrated Framework of Customer-based Brand Equity and Theory of Planned Behavior: A Meta-analysis Approach
}

\author{
Wann-Yih WU', Thi-Yen DO², Phuoc-Thien NGUYEN ${ }^{3}$, Nadia ANRIDHO ${ }^{4}$, Minh-Quan VU
}

Received: June 03, 2020 Revised: June 28, 2020 Accepted: July 09, 2020

\begin{abstract}
The objectives of this study are (1) to review previous studies in the context of brand management in consumer behaviors using costumer based brand equity (CBBE) and theory of planned behavior (TPB) as the basic foundation of the study; and (2) to develop a comprehensive research model by integrating relevant research constructs using meta-analysis. This study reviewed a total 173 studies from 58 published papers with 40 journals during 1991 2014 and developed a comprehensive framework with 16 research hypotheses. The results showed that (1) brand image, brand personality, brand association, and subjective norm are the important antecedents of brand attitudes; (2) brand awareness, brand trust, perceived quality, and perceived behavioral control are the important antecedents of brand loyalty; (3) brand attitude positively influences brand loyalty, which further influences brand equity; and (4) brand equity positively influences behavioral intention. This study fills in the research gap by integrating more research variables into CBBE model, particularly to include the influence of social context on consumer behavior through TPB. These results indicated that the integration between CBBE and TPB is meaningful and the comprehensive model can explain more variances than that of the individual model. Limitations, and recommendations for future research in this area are provided.
\end{abstract}

Keywords: Customer-Based, Brand Equity, Planned Behavior Theory, Meta-Analysis

JEL Classification Code: M00, M30, M31

\section{Introduction}

Brand is one of the important assets of a company (M'zungu et al., 2010). Increasing the effectiveness of brand

\footnotetext{
${ }^{1}$ First Author. College of Management, Nanhua University, Taiwan. Email: wwanyi888@gmail.com

${ }^{2}$ Corresponding Author. PhD Student, Department of Business Administration, Nanhua University, Taiwan [Postal Address: No. 55,

Sec. 1, Nanhua Rd., Dalin Township, Chiayi County 62249, Taiwan] Email: hannah.ba.nhu@gmail.com

${ }^{3}$ Faculty of Economics-Management, Dong Nai Technology University, Vietnam. Email: nhuanduc08@gmail.com

${ }^{4}$ Department of Accountancy, Universitas Airlangga, Indonesia. Email: nadiaanridho@gmail.com

5International School, Vietnam National University, Ha Noi, Vietnam. Email quanvm@isvnu.vn.

(c) Copyright: The Author(s)

This is an Open Access article distributed under the terms of the Creative Commons Attribution Non-Commercial License (http://Creativecommons.org/licenses/by-nc/4.0/) which permits unrestricted noncommercial use, distribution, and reproduction in any medium, provided the original work is properly cited.
}

management is an important task for manager. One way to do it is by building up strong brand equity. Many researchers and practitioners have already paid much attention to brand equity and thus, it has become a popular marketing concept (Atilgan et al., 2005). One of the famous models of brand equity is customer-based brand equity model which emphasizes on the cognitive customer-based or costumers' perceptions about a brand (Aaker, 1991; Keller, 1993). Aaker (1991) conceptualized brand equity as five components of sources: brand loyalty, brand awareness, perceived brand quality, brand associations (or brand image), and other proprietary assets (patents, trademarks, etc.). Keller (1993) viewed brand equity as the level of awereness, familiarity, the strength, favorability, and uniqueness of brand associations that consumers hold in memory. However, as Gambetti et al. (2012) mentioned, previous studies of customerbased brand equity have several weaknesses such as: (1) just focusing on the individual dimensions of consumer behavior and neglecting the influences of social, cultural, and relational context of brand equity on consumer behavior; and (2) just focusing on many fragmented views of brand 
equity. Therefore, it is difficult to develop a comprehensive framework of brand-related constructs. This study intends to fill this research gap by integrating more research variables into CBBE model, particularly to include the influence of social context on consumer behavior.

Theory of Planned Behavior (TPB) from Ajzen (1991) is one of the most important theories that is widely used to explain consumer behaviors in the literature. TPB consists of subjective norms, perceived behavioral control, attitude, and behavioral intention. Consumers' loyalty and purchasing behavior toward certain brand can be explained by TPB (Olsen, 2007). Several previous studies have evaluated TPB through meta-analysis. Among others, Notani (1998) who examined moderators of perceived behavioral control's predictiveness in TPB; Rivis and Sheeran (2003) who evaluated descriptive norms as an additional predictor in TPB; and Rise et al. (2010) who worked on the role of self-identity in TPB; etc. However, none of them conducted TPB meta-analysis in the context of brand management. Therefore, this study tries to fill in the research gap by conducting meta-analysis study to integrate $\mathrm{CBBE}$ and $\mathrm{TPB}$ into a more comprehensive research model.

The integration of CBBE and TPB is important because strong brand equity can enhance consumers' positive evaluation toward the brand which further influences repurchase behavior (Yoshida \& Gordon, 2012). Positive customer-based brand equity will lead to greater revenues, lower costs, and higher profits. It also has direct implications for company to achieve premium price, consumers' willingness to seek out new distribution channels, the effectiveness of marketing communications, and the success of brand extensions and licensing opportunities (Keller, 2003).

A plenty of empirical studies have identified the key success factors to CBBE and TPB, however, meta-analysis study in these contexts remains rare. This study seeks to review previous research and identify the effect size for each hypothesis of the integrative model which consists of the components of CBBE and TPB in consumer behavior research. Therefore, the objectives of this study are (1) to review previous studies in the context of brand management in consumer behaviors which using $\mathrm{CBBE}$ and TPB as the basic foundation of the study; and (2) to develop a comprehensive research model by integrating CBBE and TPB.

\section{Literature Review}

\subsection{The Antecedents of Brand Attitude}

This study identifies brand image, brand personality, brand association, and subjective norm as the four important antecedents of brand attitude. Brand image is essential to differentiate a product from its competitors (Ismail \& Spinelli, 2012). It is a set of perceptions about a brand as reflected by brand association held in the consumers' memory. Brand personality is defined as human characteristics which associate with a brand, while brand association is defined as the category of brand's assets and liabilities that include anything 'linked' in memory to a brand (Aaker, 1991, 1997).

Both of brand image and brand personality sometimes have been used interchangeably in several studies (Ismail \& Spinelli, 2012). This study proposes that brand image positively influences brand personality because most previous studies's results directed to that direction (Peterson, 1997; Hosany et al., 2006; Chen \& Phou, 2013; Oh \& Park, 2020). Through the brand image, brand personality can be built up (Chen \& Phou, 2013). Moreover, when product information is given about the personality of the brand, it may increase consumers' attention to the brand and stimulate active information processing which further enhances the emergence of brand association (Freling \& Forbes, 2005). Thus, the following hypotheses are developed:

\section{H1: Brand image has positive influence on brand personality.}

H2: Brand personality has positive influence on brand association.

Consumer behaviors can be influenced by internal and external factors (Lin, 2008). Brand image, brand personality, and brand association tend to influence consumers' attitude toward the brand from the internal side or consumers' cognition side. Brand image and brand association remain in consumers' memory, while brand personality used to convey consumers' ideal-self, and consumer perception can be used by the consumers to make brand evaluation (Faircloth et al., 2001; Guthrie et al., 2008). Brands with positive image and association in consumers' mind and that bear similar personality with consumers tend to lead to consumers' positive attitude toward such brands. On the other hand, subjective norm tends to influence brand attitude from the external side. Based on TPB, subjective norm is reflected by a consumer's tendency to conform to the expectations of others regarding purchase decisions making in order to gain rewards or to avoid punishment from others (Zhan \& He, 2012). Consumers tend to have the similar attitude toward a brand with other people in their community. Therefore, the following hypotheses are developed:

H3: Brand image has a positive influence on brand attitude.

H4: Brand personality has a positive influence on brand attitude. 
H5: Brand association has a positive influence on (a) brand attitude and (b) brand trust.

H6: Subjective norm has a positive influence on brand attitude.

\subsection{The Antecedents of Brand Loyalty}

Brand awareness, brand trust, perceived quality, and perceived behavioral control are the important antecedents of brand loyalty. Brand loyalty is consumers' tendency to be loyal to a brand, as demonstrated by the intention to purchase from the brand as a primary choice (Yoo \& Donthu, 2001). Brand awareness is consumers' ability to recognize or recall that a brand is a member of a certain product category. Perceived quality can be defined as consumer's overall impression of the relative superiority of the brand. Brand trust can be defined as the confident expectations of the brand's perceived credibility and benevolence (Kumar et al., 2013). This study proposes that brand awareness and perceived quality positively influence brand trust. More brand awareness and higher brand perceived quality lead to higher consumers' trust toward a brand. Thus, the following hypotheses are developed:

H7: Brand awareness has a positive influence on brand trust.

H8: Perceived quality has a positive influence on brand trust.

Furthermore, this study proposes that brand awareness, brand trust, perceived quality, and perceived behavioral control positively influence brand loyalty. Consumer with higher awareness, higher trust, and higher perceived quality toward the brand will be more committed toward that brand (Pappu et al., 2005; Anuwichanont \& Mechinda, 2009; Kumar et al., 2013). When a consumer highly trusts a brand and perceived that a brand has good quality, they tend to have higher commitment to be loyal to that brand.

In addition, Ajzen (1991) defined perceived behavioral control as the person's beliefs on how easy or difficult performance of the behavior is likely to be. Olsen (2007) defined perceived behavioral control as the internal and external resources, as well as the contextual factors that make it difficult to act upon the motivation to consume and to engage in repurchase loyalty toward a product category. Furthermore, perceived behavioral control is an important predictor of motivation, intention, and behavior (Olsen, 2007). Lee, et al. (2009) also found that perceived behavioral control positively influences consumer loyalty. Consumers may need an opportunity to be involved to consume and/or engage in repurchase loyalty (Olsen, 2007; Park \& Park, 2019). Therefore, the following hypotheses are proposed:
H9: Brand awareness has a positive influence on brand loyalty.

H10: Brand trust has a positive influence on brand loyalty.

H11: Perceived quality has a positive influence on brand loyalty.

H12: Perceived behavioral control has a positive influence on brand loyalty.

\subsection{The Effect of Brand Attitude and Brand Loyalty}

Brand attitude is consumers' overall evaluation of the brand. Brand attitude depends on consumer perceptions regarding a brand and can be a predictor of consumers' behavior toward brand (Shimp, 2010). Brand loyalty is consumer commitment to re-buy or re-patronize a preferred product or service in the future (Oliver, 1997). Previous research showed that brand attitude positively influences brand loyalty (Liu et al., 2012). Keller (1993) argued that loyalty toward a brand is an outcome of effectively managed attitude toward the brand. Consumers with more positive attitude towards a brand tend to be more loyal towards it.

Furthermore, brand attitude and brand loyalty are the key components to value brand equity (Liu et al., 2012; Moisescu \& Allen, 2010). Consumer's self-reported brand value is driven by her/his attitude toward the brand which further enhances brand equity (Faircloth et al., 2001). In addition, brand loyalty has been found to be the strongest driver of brand equity (e.g. Yoo et al., 2000; Atilgan et al., 2005; Yasin et al., 2007; Buil et al., 2013). Loyal consumers show more favorable responses toward a brand which further contribute to the growth of brand equity. Therefore, the following hypotheses are developed:

H13: Brand attitude has a positive influence on brand loyalty.

H14: Brand attitude has a positive influence on brand equity.

H15: Brand loyalty has a positive influence on brand equity.

\subsection{The Effect of Brand Equity}

Brand equity is one of the core concepts in marketing (Buil et al., 2013). Aaker (1991) defined brand equity as "a set of brand assets and liabilities linked to a brand, its name and symbol that add to or subtract from the value provided by a product or service to a firm and/or to that firm's customers". Brand value can be derived from the impact of brand knowledge on consumer's response to the brand marketing (Aaker, 1991; Agarwal \& Rao, 1996; Keller, 1993). 
Previous research showed that brand equity reinforces consumers' attitudinal and behavioral loyalty at the individual consumer level (Yoshida and Gordon, 2012). Brand equity can lead to consumers' intentions to repurchase a product, positive word-of-mouth intentions, and consumers' retention over time (Cobb-Walgren et al., 1995; Johnson et al., 2006; Vogel et al., 2008; Yoshida \& Gordon, 2012; Buil et al., 2013). Thus, the following hypothesis is developed:

H16: Brand equity has a positive influence on behavioral intention.

\section{Methodology}

\subsection{Research Model}

Based on the literature review of CBBE and TPB in brand management, an integrated research model is developed as shown in Figure 1. This meta-analysis model describes the relationship between the components of CBBE (e.g., brand image, brand association, brand awareness, perceived quality, brand loyalty, and brand equity) and TPB (e.g., brand attitude, subjective norms, perceived behavioral control, and behavioral intention). Brand personality and brand trust are also included because authors see that those two constructs are considered important by many researchers in the brand management research.

Brand image, brand personality, brand association, and subjective norms are the important antecedents of brand attitude while brand awareness, brand trust, perceived quality, and perceived behavioral control are the important antecedents of brand loyalty. Furthermore, brand attitude positively influences brand loyalty; and both brand attitude and brand loyalty positively influence brand equity which further enhance consumers' behavioral intention.

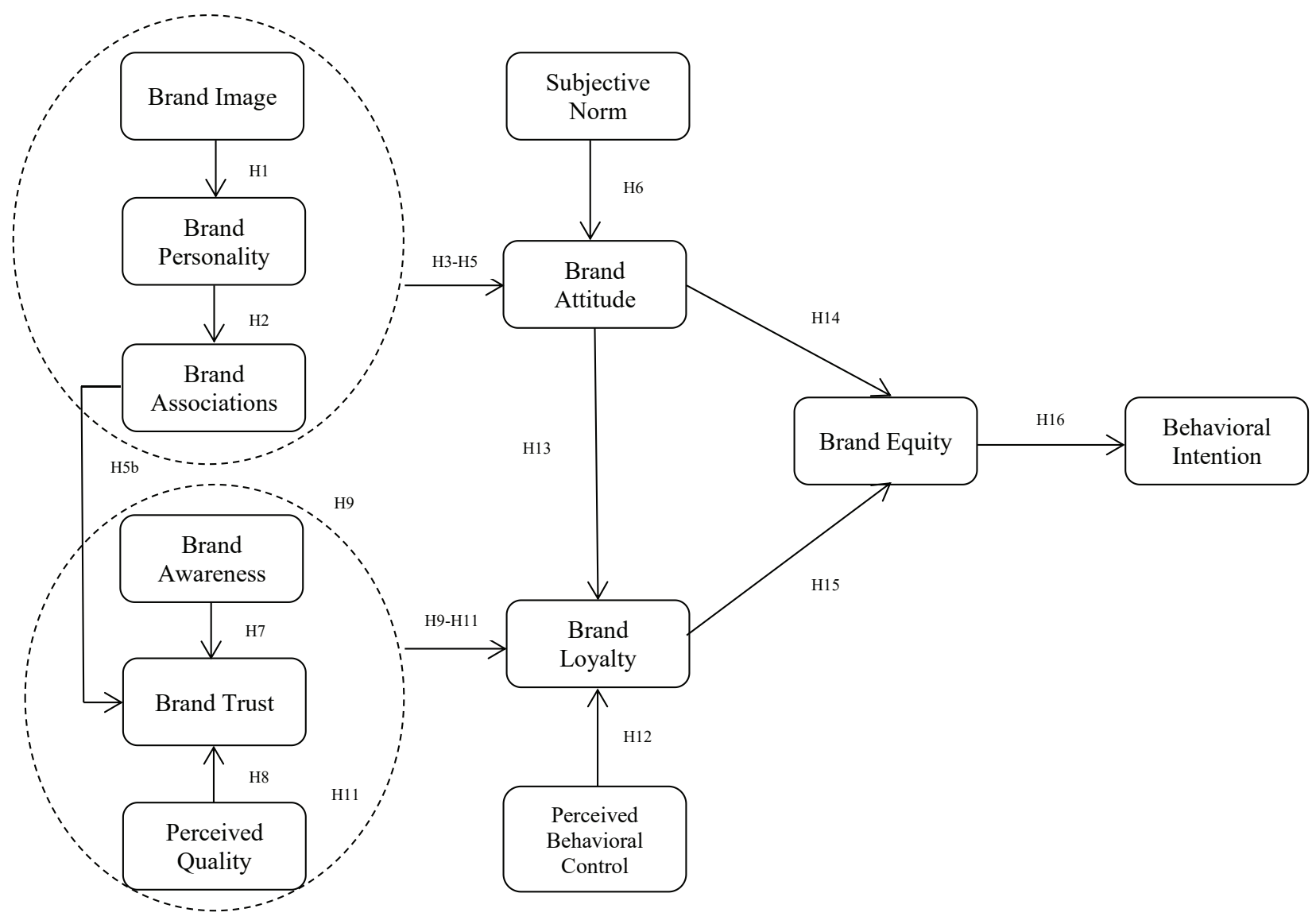

Figure 1: Research model 


\subsection{Meta-Analysis}

This study employs meta-analysis study to empirically test the above 16 research hypotheses. Meta-analysis is the process to summarize, to evaluate, and to analyze the findings of quantitative research (Kirca \& Yaprak, 2010). In case that some primary studies lack of sufficient power (i.e., sample size) to achieve significant results, meta-analysis is important to solve that problem (Lipsey \& Wilson, 2001). Meta-analysis can be more accurate to conclude the conflicting findings by correcting the distorting effects of artifacts into a single estimation result from multiple independent studies that bear on the same relationship (Hunter \& Schmidt, 2004).

To collect the data, this study firstly sought the relevant literatures in various databases such as ABI/Inform, JSTOR, Elsevier Science Direct, Wiley Online Library, Taylor \& Francis Online Journals, and many others. Keywords which related consumer-based brand equity and theory of planned behavior (e.g., brand awareness, brand attitude, brand loyalty, etc.) were used to find the suitable data for this study.

Total 173 studies from 58 published papers written in English were included in this study. All papers have brand management foundation in consumer behaviors field. In order to measure the effect size of the hypotheses, this study used correlation coefficient ( $r$ ) between two variables. The reason for using correlation coefficient as the primary effect size is that because it is easier to be interpreted and most of meta-analytical studies have used it as the criteria (Byron \& Khazanchi, 2010; Shrinivas \& Shaffer, 2005; Hechenova, 2003). Comprehensive Meta-Analysis (CMA) 2 software was used to calculate the correlations coefficient which obtained from $r$ value, $t$-value, $z$-value, and $p$-value in each paper. Effect size results (r) can be categorized into small ( $\mathrm{r}$ $<0.1)$, medium $(\mathrm{r}=0.25)$, and large $(\mathrm{r}>0.40)$; as suggested by Lipsey and Wilson (2001).

Furthermore, Q-statistic test was adopted to check the homogeneity of the effect size distribution. Lipsey and Wilson (2001) explained that Q-statistic is distributed as a chi-square with degree of freedom $=n-1$, where $n=$ number of studies. This Q-statistic test has assumed that all of the effect sizes estimating the same population mean is a reasonable assumption. The criterion for Q-statistic is that Q-value should be higher than Chi-square, and then it suggests that the null hypothesis of homogeneity is rejected. In this case, it can be concluded that the differences in effect size may be attributed to factors other than sampling. Therefore, the heterogeneity between the variance existed.

Table 1 shows the coding of all the studies which is included in this study. The sources for 58 published papers are come from 40 different journal publications.

\subsection{Structural Equation Model}

In order to test if our research model is fit, we run structural equation modelling using LISREL. Correlation coefficient matrix and median sample size were used as data input. We analyzed path coefficient and goodness of fit results.

\section{Results and Discussions}

\subsection{Meta-Analysis}

Table 2 shows the meta-analysis results for this study. The correlations (r) shown are the mean values of correlations among previous studies. First, for the antecedents of brand attitude (H1-H6), the results show that brand image has positive influence on brand personality $(\mathrm{r}=0.491)$ and brand attitude ( $\mathrm{r}=0.349)$; brand personality has positive influences on association $(\mathrm{r}=0.198)$ and brand attitude $(\mathrm{r}=0.273)$; brand association $(\mathrm{r}=0.266)$ and subjective norm $(\mathrm{r}=0.429)$ have positive influence on brand attitude. Furthermore, brand association $(\mathrm{r}=0.734)$ also has positive influence on brand trust. All of the hypotheses have Q-values higher than Chisquare except for $\mathrm{H} 2$ and $\mathrm{H} 5 \mathrm{~b}$ but the difference is not big. It means that these hypotheses are significantly heterogeneous from the variance attributed to factors rather than from the sampling errors. Thus, H1 until H6 are supported.

Brand image positively influences brand personality. This resultis in line with previous studies (e.g., Chen \& Phou, 2013; Hosany et al., 2006). Brand personality can be built up by the image of the brand. Brand personality also positively influences brand associations (Freling \& Forbes, 2005). When product information is given about the personality of the brand, it leads to the emergence of brand association. Furthermore, brand image, brand personality, brand associations, and subjective norm positively influence brand attitude (Faircloth et al., 2001; O'Cass \& Grace, 2003; Guthrie et al., 2008; Lin, 2008; Zhan \& He, 2012; Lee \& Kang, 2013). A brand which has positive image and association in consumers' mind and has similar personality with consumers tends to lead to consumers' positive attitude toward the brand. Consumers also may choose a brand or evaluate a brand positively when the other people around them also have the same evaluation.

Second, for the antecedents of brand loyalty (H7H12), the results show that brand awareness $(\mathrm{r}=0.372)$ and perceived quality $(\mathrm{r}=0.689)$ have positive influence on brand trust; brand awareness $(\mathrm{r}=0.415)$, brand trust $(\mathrm{r}=0.597)$, perceived quality $(\mathrm{r}=0.218)$, and perceived behavioral control $(\mathrm{r}=0.169)$ have positive influence on brand loyalty. All of the hypotheses have Q-values higher than Chi-square except for $\mathrm{H} 12$ but the difference is not big. It means that these hypotheses are significantly heterogeneous from the 
Table 1: Studies alphabetically by source and codes for hypotheses tests $a, b$

\begin{tabular}{|c|c|}
\hline \multicolumn{2}{|c|}{ Studies Alphabetically by Source and Codes for Hypotheses Tests } \\
\hline 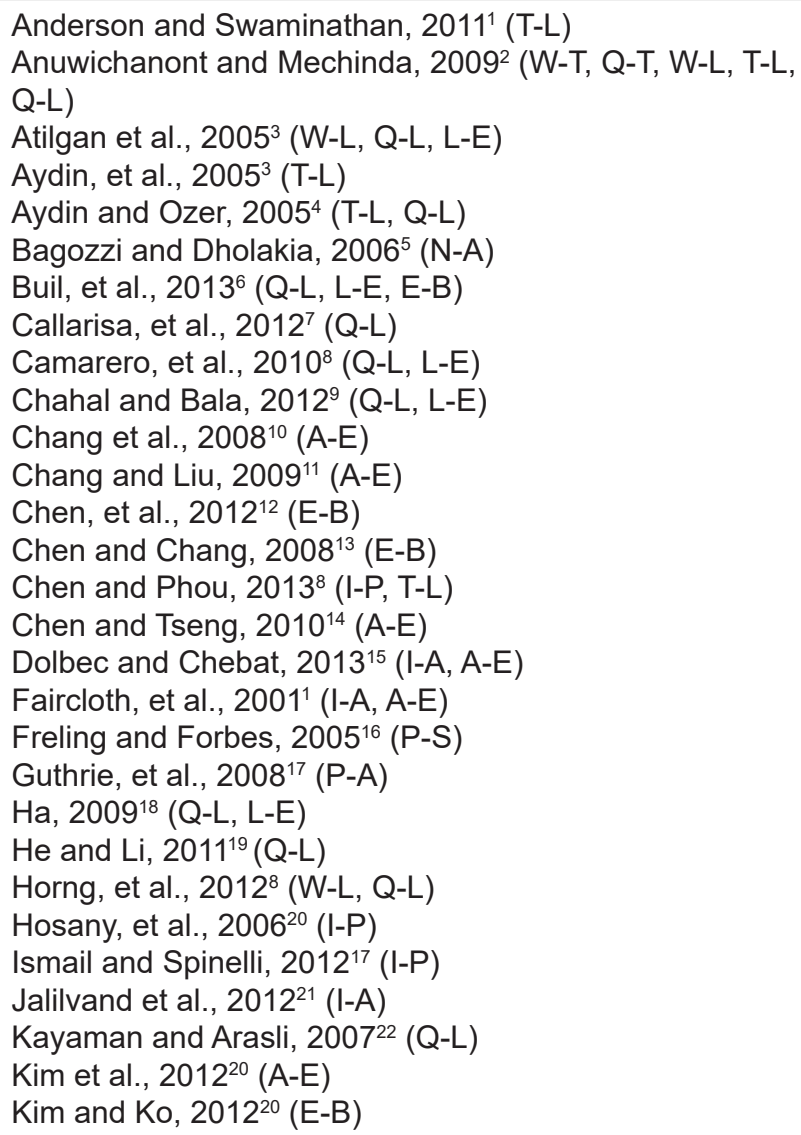 & 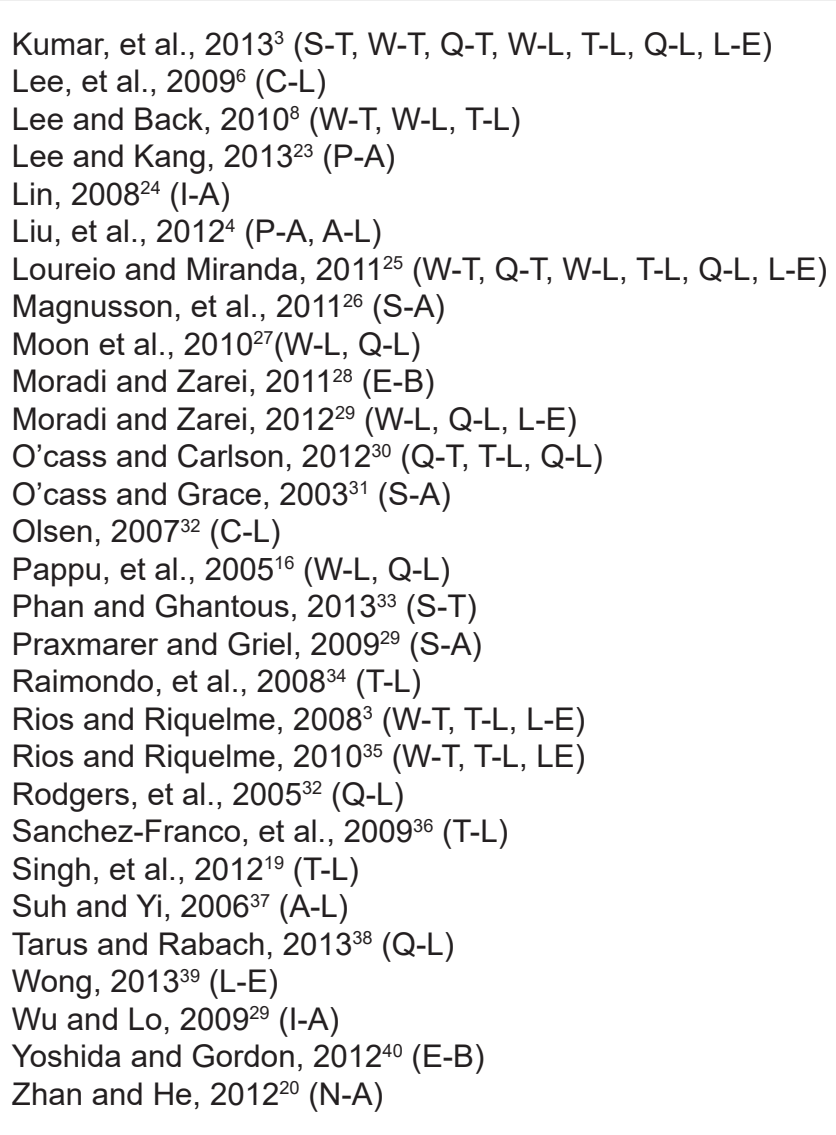 \\
\hline
\end{tabular}

aCodes in parentheses:I= Brand Image; P= Brand Personality; S= Brand Association; W= Brand Awareness; T= Brand Trust; Q= Perceived Quality; N= Subjective Norm; A= Brand Attitude; L= Brand Loyalty; C= Perceived Behavioral Control; E= Brand Equity; B= Behavioral Intention.

bJournals are footnoted in alphabetical order: (1)Journal of Marketing Theory and Practice, (2)Journal of Business \& Economic Research, (3)Marketing Intelligence \& Planning, (4)European Journal of Marketing, (5)International Journal of Research in Marketing, (6)Journal of Consumer Marketing, (7)Tourism Management Perspectives, (8)Tourism Management, (9)International Journal of Health Care Quality Assurance, (10)Asia Pacific Management Review, (11)The Service Industries Journal, (12)Social Behavior and Personality, (13)Journal of Air Transport Management, (14)Transportation Journal, (15)Journal of Retailing, (16)Journal of Product \& Brand Management, (17)Journal of Fashion Marketing and Management, (18)Seoul Journal of Business, (19)Journal of Business Ethics, (20)Journal of Business Research, (21)Journal of Destination Marketing \& Management, (22)Managing Service Quality, (23)Academy of Marketing Studies Journal, (24)International Journal of Commerce \& Management, (25)Journal of Service Science and Management, (26)International Marketing Review, (27)Journal of Global Academy of Marketing Science, (28)Australian Journal of Basic and Applied Sciences, (29)Asia Pacific Journal of Marketing and Logistics, (30)Australasian Marketing Journal, (31)Journal of Services Marketing, (32)Psychology and Marketing, (33)International Journal of Bank Marketing, (34)Journal of Service Research, (35)Journal of Research in Interactive Marketing, (36) Information \& Management, (37)Journal of Consumer Psychology, (38)The TQM Journal, (39)International Journal of Hospitality Management, (40)Sport Management Review.

variance attributed to factors rather than from the sampling errors. Therefore, $\mathrm{H} 7$ until $\mathrm{H} 12$ are supported.

Both of brand awareness and perceived quality positively influence brand trust. The results are in line with previous studies (e.g., Anuwichanont \& Mechinda, 2009; Kumar et al., 2013). Moreover, brand awareness, brand trust, perceived quality, and perceived behavioral control positively influence brand loyalty (Aydin et al., 2005; Pappu et al., 2005; Olsen, 2007; Lee et al., 2009; Kumar et al., 2013). Consumer with high awareness, high trust, high perceived quality of the brand, and high opportunity to be involved in purchase decision making will be more committed toward that brand. 
Table 2: Meta-analysis results

\begin{tabular}{|c|c|c|c|c|c|c|c|c|c|c|c|}
\hline \multirow{2}{*}{ H. } & \multicolumn{2}{|c|}{ Variables } & \multirow[t]{2}{*}{$\begin{array}{c}\mathbf{k} \\
\text { Studies }\end{array}$} & \multirow[t]{2}{*}{$\begin{array}{c}\text { Total } \\
\mathbf{N}\end{array}$} & \multicolumn{3}{|c|}{$\begin{array}{l}\text { Effect Size \& 95\% } \\
\text { Confidence Interval }\end{array}$} & \multicolumn{4}{|c|}{ Heterogeneity } \\
\hline & Independent & Dependent & & & $r$ & $\mathrm{LCl}$ & UCl & $p$-value & $\begin{array}{l}\text { Chi- } \\
\text { square }\end{array}$ & Q-value & I-squared \\
\hline 1 & Brand Image & $\begin{array}{l}\text { Brand } \\
\text { Personality }\end{array}$ & 3 & 826 & 0.491 & 0.437 & 0.541 & 0.000 & 13.816 & 21.293 & 90.607 \\
\hline 2 & $\begin{array}{l}\text { Brand } \\
\text { Personality }\end{array}$ & $\begin{array}{l}\text { Brand } \\
\text { Association }\end{array}$ & 5 & 960 & 0.198 & 0.136 & 0.258 & 0.901 & 1.064 & 1.056 & 0.000 \\
\hline 3 & Brand Image & $\begin{array}{l}\text { Brand } \\
\text { Attitude }\end{array}$ & 8 & 1772 & 0.349 & 0.307 & 0.389 & 0.000 & 24.322 & 70.276 & 90.039 \\
\hline 4 & $\begin{array}{l}\text { Brand } \\
\text { Personality }\end{array}$ & \begin{tabular}{|l|} 
Brand \\
Attitude
\end{tabular} & 21 & 5099 & 0.273 & 0.247 & 0.299 & 0.000 & 45.315 & 282.278 & 92.915 \\
\hline $5 a$ & $\begin{array}{l}\text { Brand } \\
\text { Associations }\end{array}$ & $\begin{array}{l}\text { Brand } \\
\text { Attitude }\end{array}$ & 4 & 1293 & 0.266 & 0.215 & 0.316 & 0.003 & 12.838 & 14.299 & 79.019 \\
\hline $5 b$ & $\begin{array}{l}\text { Brand } \\
\text { Association }\end{array}$ & Brand Trust & 4 & 2573 & 0.734 & 0.715 & 0.751 & 0.316 & 3.66 & 3.538 & 15.194 \\
\hline 6 & $\begin{array}{l}\text { Subjective } \\
\text { Norm }\end{array}$ & \begin{tabular}{|l} 
Brand \\
Attitude
\end{tabular} & 3 & 768 & 0.429 & 0.369 & 0.485 & 0.000 & 13.816 & 83.478 & 97.604 \\
\hline 7 & $\begin{array}{l}\text { Brand } \\
\text { Awareness }\end{array}$ & Brand Trust & 7 & 3304 & 0.372 & 0.342 & 0.401 & 0.000 & 22.458 & 246.585 & 97.567 \\
\hline 8 & $\begin{array}{l}\text { Perceived } \\
\text { Quality }\end{array}$ & Brand Trust & 4 & 2247 & 0.689 & 0.666 & 0.710 & 0.000 & 16.266 & 121.450 & 97.530 \\
\hline 9 & $\begin{array}{l}\text { Brand } \\
\text { Awareness }\end{array}$ & \begin{tabular}{|l} 
Brand \\
Loyalty
\end{tabular} & 15 & 5423 & 0.415 & 0.392 & 0.437 & 0.000 & 36.123 & 249.363 & 94.386 \\
\hline 10 & Brand Trust & $\begin{array}{l}\text { Brand } \\
\text { Loyalty }\end{array}$ & 20 & 19027 & 0.597 & 0.588 & 0.606 & 0.000 & 43.820 & 3028.47 & 99.373 \\
\hline 11 & $\begin{array}{l}\text { Perceived } \\
\text { Quality }\end{array}$ & $\begin{array}{l}\text { Brand } \\
\text { Loyalty }\end{array}$ & 31 & 58586 & 0.218 & 0.210 & 0.226 & 0.000 & 59.703 & 3650.69 & 99.178 \\
\hline 12 & PBC & \begin{tabular}{|l} 
Brand \\
Loyalty
\end{tabular} & 4 & 1533 & 0.169 & 0.119 & 0.217 & 0.951 & 0.352 & 0.346 & 0.000 \\
\hline 13 & $\begin{array}{l}\text { Brand } \\
\text { Attitude }\end{array}$ & $\begin{array}{l}\text { Brand } \\
\text { Loyalty }\end{array}$ & 4 & 2468 & 0.495 & 0.464 & 0.524 & 0.000 & 16.266 & 46.402 & 93.535 \\
\hline 14 & $\begin{array}{l}\text { Brand } \\
\text { Attitude }\end{array}$ & $\begin{array}{l}\text { Brand } \\
\text { Equity }\end{array}$ & 12 & 1740 & 0.458 & 0.419 & 0.494 & 0.000 & 26.757 & 261.759 & 95.798 \\
\hline 15 & $\begin{array}{l}\text { Brand } \\
\text { Loyalty }\end{array}$ & \begin{tabular}{|l|} 
Brand \\
Equity \\
\end{tabular} & 13 & 5254 & 0.598 & 0.579 & 0.616 & 0.000 & 28.300 & 389.661 & 97.177 \\
\hline 16 & Brand Equity & \begin{tabular}{|l|} 
Behavioral \\
Intention
\end{tabular} & 8 & 3279 & 0.409 & 0.380 & 0.437 & 0.000 & 20.278 & 334.162 & 97.905 \\
\hline
\end{tabular}

Third, brand attitude has a positive influence on brand loyalty $(\mathrm{r}=0.495)$ and brand equity $(\mathrm{r}=0.458)$; while brand loyalty has a positive influence on brand equity $(\mathrm{r}=0.598)$. All of the hypotheses have Q-values higher than Chi-square. It means that these hypotheses are significantly heterogeneous from the variance attributed to factors rather than from the sampling errors. Thus, H13, H14, and H15 are supported.
Brand attitude positively influences brand loyalty. This resultsis in line with Suh and Yi (2006) and Liu, et al.(2012). Consumers with more positive attitude towards a brand tend to be more loyal. Both brand attitude and brand loyalty positively influence brand equity (Faircloth et al., 2001; Atilgan et al., 2005; Kim et al., 2012; Buil et al., 2013) Consumer's self-reported brand value is driven by her/his 
attitude toward the brand and loyal consumers show more favorable response to a brand which further leads to greater brand equity.

Finally, brand equity has a positive influence on behavioral intention $(\mathrm{r}=0.409)$. ItsQ-value is higher than Chi-square. It means that these hypotheses are significantly heterogeneous from the variance attributed to factors rather than from the sampling errors. Therefore, H16 is supported. The result is in line with previous studies (Chen \& Chang, 2008; Moradi \& Zarei, 2011; Chen et al., 2012; Kim \& Ko, 2012; Yoshida \& Gordon, 2012; Buil et al., 2013). Consumers who perceive a higher value in a brand are more likely to buy it (Aaker, 1991). Consumers are more willing to purchase a product at a higher price which implies greater brand equity for the brand (Chen et al., 2012). It indicates stronger purchase intention in consumer's mind.

\subsection{Structural Equation Model}

Figure 2 shows the results of path coefficients of SEM. Goodness of fit index shows that the proposed model is fit with previous meta-analysis statistics. GFI $=0.980$, $\mathrm{AGFI}=0.959, \mathrm{SRMR}=0.0315$, and $X^{2}(38)=293.84, \mathrm{p}<0.001$.
All the results are consistent with meta-analysis results which are positive significant except for H4 (brand personality-brand attitude) which shows non-significant result. The non-significant result for the effect of brand personality on brand attitude may be due to the divergence of previous findings. Liu, et al. (2012) also found that brand personality has no effect on brand attitude.

Brand loyalty shows stronger effect on brand equity $(\beta=0.316)$ than brand attitude $(\beta=0.272)$. This result is also shown in meta-analysis result. Brand loyalty has higher $r$ value $(0.458)$ than brand attitude $(0.598)$. It is consistent with previous studies that brand loyalty is the strongest predictor of brand equity (Atilgan et al., 2005).

\section{Conclusions and Limitations}

\subsection{Conclusions}

The objectives of this study are (1) to review previous studies in the context of brand management in consumer behaviors which using $\mathrm{CBBE}$ and TPB as the basic foundation of the study, and (2) to develop a comprehensive research model by integrating $\mathrm{CBBE}$ and TPB. Through the

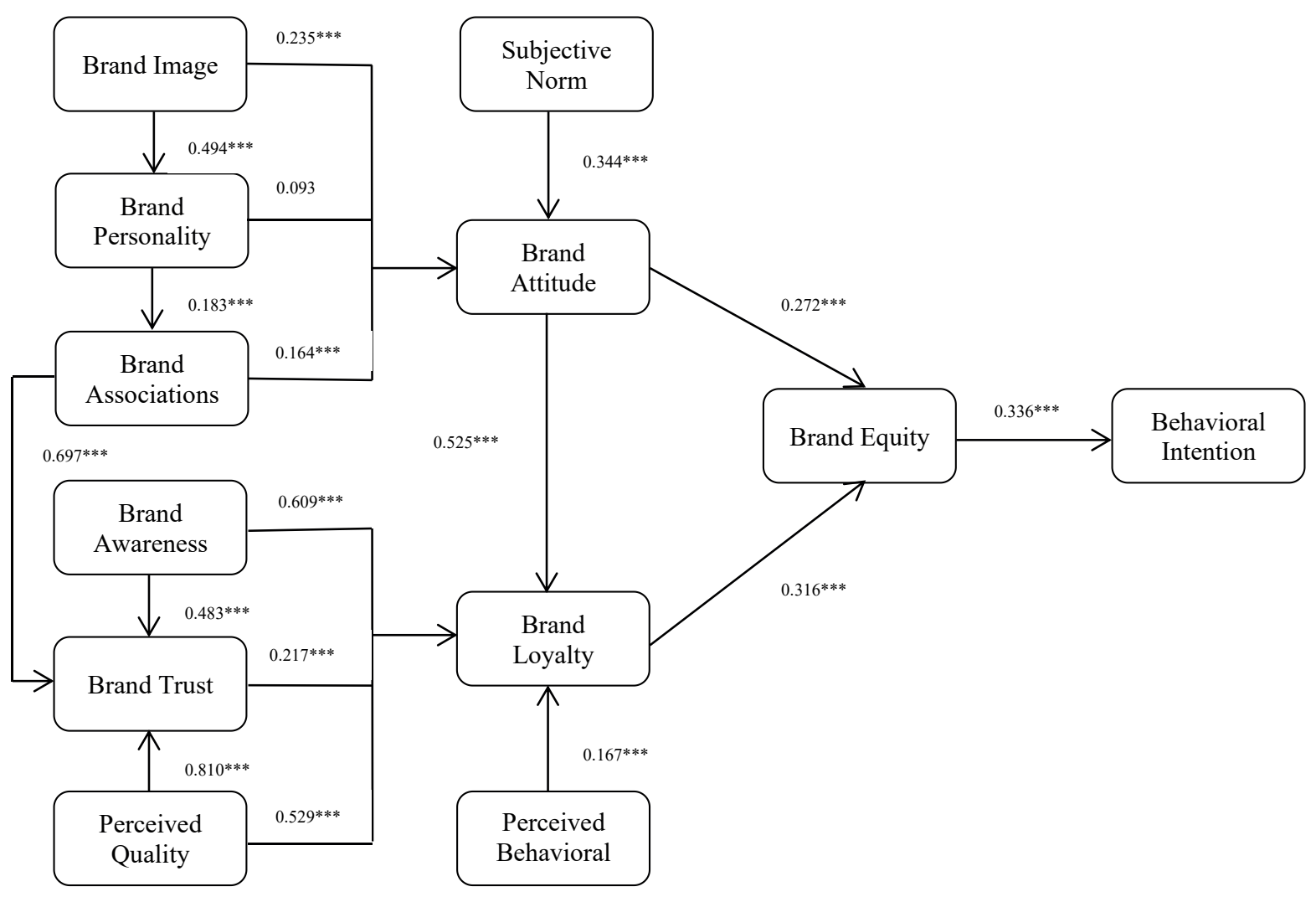

Figure 2: Structural Equation Modelling Estimation 
meta-analysis study, this study reviewed 173 studies in total from 58 published papers during 1991-2014 and developed a comprehensive framework with 16 hypotheses. The research framework was tested using the mean values of correlations between dependent and independent variables out of the results of 173 previous studies.

The results from meta-analysis show that all 16 hypotheses were supported. These results further suggested that the extension of CBBE model to include variables from TPB (such as brand attitude, subjective norms, and perceived behavioral control), brand personality, and brand association seems to explain more variance on consumer's brand choice behavior. Furthermore, to test the proposed model fitness, this study applied structural equation modelling. From 17 paths of relationship, 1 path is not significant at the 0.05 level.

For academic implication, the research model as developed in this study integrated consumer-based brand equity (CBBE) model and theory of planned behavior (TPB) model and additional constructs. As previous studies have examined those two theories separately, this study contributes to the marketing literature, especially to the brand management research context, with a development of a more comprehensive research model related to consumer behavior. From the research framework, it can be seen that brand equity is one of the factors that can enhance consumers repurchase intention.

This study attempts to fill in the research gap by integrating more research variables into CBBE model, particularly to include the influence of social context on consumer behavior through TPB. As mentioned earlier, CBBE focuses on brandrelated constructs on brand equity without considering the influences of social contexts which are one of the important determinants in consumer's choice of a brand. This study added several constructs such as subjective norm, perceived behavioral control, brand personality, brand trust, and brand attitude to demonstrate the complexity of brand choice. For example, positive attitude toward a brand will contribute to building up strong brand equity. Consumer' positive attitude arises because of that brand itself (i.e., has good image in consumers' mind) or because the influence of people around them. Moreover, consumer's perceived behavioral control can enhance brand loyalty which further contributes to strong brand equity.

Although a plenty of previous studies have investigated the influence of specific antecedents on brand equity, nearly none of them have integrated above constructs into a more comprehensive framework (Gambetti et al., 2012). This study follows Zhang, et al. (2012) who argued that "inevitable problem of inconsistent empirical findings on essentially the same question need to be integrated and presented as a general conclusion" (p.1909). Therefore, the extended CBBE model as adopted in this study contributes to the academic field by integrating 173 studies into a comprehensive research model which a subject to further empirical validation.

For managerial implication, one of the most important things to do for brand managers isthat to design an effective brand management (e.g., leverage brand equity) in order to increase brand value. It is important because strong brand equity significantly enhances the positive evaluation of the brand and the repeated purchasing. Marketers engage in projects to understand and improve the authenticity their brands provide for their customers (Tran et al., 2020). Brand managers should pay more attention not solely on brand-related constructs, but also from social context. It is recommended that brand-related constructs will not be the only secret weapon to achieve competitive advantages. Managers need to carefully consider the elements like subjective norms and perceived behavioral control that may relate more to consumers. Marketing activities should be more focused on creating brand personality for the brand. Building up strong loyal consumers is important because once consumers are loyal to a particular brand they are likely to give positive information about that brand to another people (positive word-of mouth).

\subsection{Limitations and Future Research}

This study has several limitations. First, the comprehensive research model as developed in this study is subject to further empirical validation. Therefore, future research can verify this research model through in-depth interviews, case studies, or questionnaire surveys. Second, to increase the capacity of explanation, the comprehensive research model may subject tobe modified by integrating more theories and constructs into the model. Third, each of the reviewed paper may have different measurement and data collection methods. Future research may have to evaluate the measurement scales and collection methods in order to get more solid results in terms of measurement. Second, the reviewed papers in this study were limited to the papers that published in journal publication written in English. Future research may review more papers which related with $\mathrm{CBBE}$ and TPB in unpublished papers (e.g., dissertation, conference paper) and papers written in other languages.

\section{References}

Aaker, D. A. (1991). Managing brand equity: capitalizing on the value of a brand name, New York, NY: The Free Press.

Ajzen, I. (1991). The theory of planned behavior. Organisational Behaviour and Human Decision Process, 50, 179-211.

Anuwichanont, J., \& Mechinda, P. (2009). The impact of perceived value on spa loyalty and its moderating effect of destination equity. Journal of Business \& Economics Research, 7(12), 73-89. 
Atilgan, E., Aksoy, S., \& Akinci, S. (2005). Determinants of the brand equity: A verification approach in the beverage industry in Turkey. Marketing Intelligence \& Planning, 23(3), 237-248.

Aydin, S., Gokhan, O., \& Arasil, O. (2005). Customer loyalty and the effect of switching costs as a moderator variable: A case in the Turkish mobile phone market. Marketing Intelligence \& Planning, 23(1), 89-103.

Bagozzi, R. P., \& Dholakia, U. M. (2006). Antecedents and purchase consequences of customer participation in small group brand communities. International Journal of Research in Marketing, 23(1), 45-61.

Buil, I., Martinez, E., \& de Chernatony, L. (2013). The influence of brand equity on consumer responses. Journal of Consumer Marketing, 30(1), 62-74.

Chen, C. C., Chen, P. K., \& Huang, C. E. (2012). Brands and consumer behavior. Social Behavior and Personality, 40(1), 105-114.

Chen, C. F., \& Chang, Y. Y. (2008). Airline brand equity, brand preference, and purchase intentions - The moderating effects of switching cost. Journal of Air Transport Management, 14(1), 40-42.

Chen, C. F., \& Phou, S. (2013). A closer look at destination: Image, personality, relationship and loyalty. Tourism Management, 36, 269-278.

Dolbec, P. Y., \& Chebat, J. C. (2013). The impact of a flagship vs. a brand store on brand attitude, brand attachment, and brand equity. Journal of Retailing, 89(4), 460-466.

Faircloth, J. B., Capella, L. M., \& Alford, B. L. (2001). The effect of brand attitude and brand image on brand equity. Journal of Marketing Theory and Practice, 9(3), 61-75.

Freling, T. H., \& Forbes, L. P. (2005). An empirical analysis of the brand personality effect. Journal of Product \& Brand Management, 14(7), 404-413.

Guthrie, M., Kim, H. S., \& Jung, J. H. (2008). The effects of facial image and cosmetic usage on perceptions of brand personality. Journal of Fashion Marketing and Management, 12(2), 164181.

Hosany, S., Ekinci, Y., \& Uysal, M. (2006). Destination image and destination personality: An application of branding theories to tourism places. Journal of Business Research, 59(5), 638-642.

Hunter, J.E., \& Schmidt, F.L. (2004). Methods of Meta-Analysis: Correcting Error and Bias in Research Findings (2nd ed.). Thousand Oaks, CA: Sage Publications.

Ismail, A. R., \& Spinelli, G. (2012). Effects of brand love, personality and image on word of mouth: The case of fashion brands among young consumers. Journal of Fashion Marketing and Management, 16(4), 386-398.

Jalilvand, M. R., Samiei, N., Dini, B., \& Manzari, P. Y. (2012). Examining the structural relationships of electronic word of mouth, destination image, tourist attitude toward destination and travel intention: An integrated approach. Journal of Destination Marketing \& Management, 1(1-2), 134-143.
Keller, K. L. (1993). Conceptualizing, measuring, and managing customer-based brand equity. Journal of Marketing, 57(1), $1-22$.

Kim, A. J., \& Ko, E. J. (2012). Do social media marketing activities enhance customer equity? An empirical study of luxury fashion brand. Journal of Business Research, 65(10), 1480-1486.

Kumar, R. S., Dash, S., \& Purwar, P. C. (2013). The nature and antecedents of brand equity and its dimensions. Marketing Intelligence \& Planning, 31(2), 141-159.

Lee, H. J., \& Kang, M. S. (2013). The effect of brand personality on brand relationship, attitude, and purchase intention with a focus on brand community. Academy of Marketing Studies Journal, 17(2), 85-97.

Lee, R., Murphy, J., \& Neale, L. (2009). The interactions of consumption characteristics on social norms. Journal of Consumer Marketing, 26(4), 277-285.

Lin, W. B. (2008). Construction of on-line consumer behavior models: a comparative study of industries in Taiwan. International Journal of Commerce \& Management, 18(2), 123-149.

Lipsey, M. W., \& Wilson, D. B. (2001). Practical Meta-Analysis, Thousand Oaks, CA: Sage Publications.

Liu, F., Li, J., Mizerski, D., \& Soh, H. (2012). Self-congruity, brand attitude, and brand loyalty: A study on luxury brands. European Journal of Marketing, 46(7/8), 922-937.

M'zungu, S. D. M., Merrilees, S., \& Miller, D. (2010). Brand management to protect brand equity: A conceptual model. Journal of Brand Management, 17(8), 605-617.

Magnusson, P., Westjohn, S. A., \& Zdravkovic, S. (2011). What? I thought Samsung was Japanese": Accurate or not, perceived country of origin matters. International Marketing Review, 28(5), 454-472.

Moisescu, O. I., \& Allen, B. (2010). The relationship between the dimensions of brand loyalty. Management \& Marketing Challenges for Knowledge Society, 5(4), 83-98.

Oh, A. H., \& Park, H. Y. (2020). The Effect of Airline's Professional Models on Brand Loyalty: Focusing on Mediating Effect of Brand Attitude. Journal of Asian Finance, Economics, and Business, 7(5), 155-166. https://doi.org/10.13106/jafeb.2020. vol7.no5.155

O'Cass, A., \& Grace, D. (2003). An exploratory perspective of service brand associations. Journal of Services Marketing, 17(5), 452-475.

Olsen, S. O. (2007). Repurchase loyalty: The role of involvement and satisfaction. Psychology \& Marketing, 24(4), 315-341.

Park, H., \& Park, S. (2019). The Effect of Emotional Image on Customer Attitude. Journal of Asian Finance, Economics and Business, 6(3), 259-268. https://doi.org/10.13106/jafeb.2019. vol6.no3.259

Pappu, R., Quester, P. G., \& Cooksey, R. W. (2005). Consumerbased brand equity: improving the measurement - empirical 
evidence. Journal of Product \& Brand Management, 14(3), 143-154.

Praxmarer, S., \& Gierl, H. (2009). The effects of positive and negative ad-evoked associations on brand attitude. Asia Pacific Journal of Marketing and Logistics, 21(4), 507-520.

Suh, J. C., \& Yi, Y. J. (2006). When brand attitudes affect the customer satisfaction-loyalty relation: The moderating role of product involvement. Journal of Consumer Psychology, 16(2), $145-155$.

Tran, V. D., Vo, T. N. L., \& Dinh, T. Q. (2020). The Relationship between Brand Authenticity, Brand Equity and Customer Satisfaction. Journal of Asian Finance, Economics, and Business, 7(4), 213-221. https://doi.org/10.13106/jafeb.2020. vol7.no4.213
Wu, S. I., \& Lo, C. L. (2009). The influence of core-brand attitude and consumer perception on purchase intention towards extended product. Asia Pacific Journal of Marketing and Logistics, 21(1), 174-194.

Yoshida, M., \& Gordon, B. (2012). Who is more influenced by customer equity drivers? A moderator analysis in a professional soccer context. Sport Management Review, 15(4), 389-403.

Zhan, L., \& He, Y. (2012). Understanding luxury consumption in China: Consumer perceptions of best-known brands. Journal of Business Research, 65(10), 1452-1460.

Zhang, L., Zhu, J., \& Liu, Q. (2012). A meta-analysis of mobile commerce adoption and the moderating effect of culture. Computers in Human Behavior, 28(5), 1902-1911. 